\title{
Tüketicilerin Çevrim İçi İtkisel Satın Alma Davranışlarında Elektronik Hizmet Kalite Boyutlarının ve Hedonik Gezinmenin Etkisi
}

\author{
(Araştırma Makalesi)
}

\section{The Effect of Electronic Service Quality Dimensions and Hedonic Browsing on Online Impulsive Buying Behavior of Consumers}

Doi: 10.29023/alanyaakademik.691747

Mehmet Ozan KARAHAN

Öğr. Gör. Dr., Uşak Üniversitesi, Eşme Meslek Yüksekokulu

mozan.karahan@usak.edu.tr

Orcid No: 0000-0001-7287-5904

Bu makaleye atıfta bulunmak için: Karahan, M.O., (2020). Tüketicilerin Çevrim İçi İtkisel Satın Alma Davranışlarında Elektronik Hizmet Kalite Boyutlarının ve Hedonik Gezinmenin Etkisi. Alanya Akademik Bakıs, 4(3), Sayfa No. 993-1013.

\section{Anahtar kelimeler: \\ Çevrim içi İtkisel \\ Satın Alma, \\ Elektronik Hizmet \\ Kalite Boyutlarl, \\ Hedonik Gezinme, \\ Itkisel Satın Alma \\ Dürtüsü}

Makale Geliş Tarihi:

20.02.2020

Kabul Tarihi:

03.09.2020

Keywords:

Online Impulsive

Buying, Electronic

Service Quality

Dimensions, Hedonic

Browsing, Urge to

Buy Impulsively

\section{ÖZET}

Araştırmanın temel amacı elektronik hizmet kalite boyutlart, itkisel satın alma dürtüsü ve hedonik gezinme değișkenlerinin çevrim içi itkisel satın alma davranışı üzerindeki etkilerinin incelenmesidir. Araştırmanın ana kütlesini Türkiye'deki 18 yaşından büyük bireyler oluşturmaktadır. Araştırmada iliş̧kisel araştırma modelinden yararlanılmışırı. Verilerin analizi ve öne sürülen araştırma hipotezlerinin testi için yapısal eşitlik modellemesi kullanılmıştır. Toplam 338 geçerli veri ile gerçekleştirilen analizler sonucunda elektronik hizmet kalite boyutlarindan tasarım ve güvenlik/gizliliğin bireylerin itkisel satın alma dürtüsünü olumlu yönde etkilediği görülmektedir. Ayn şekilde, internette hedonik gezinme, bireylerin itkisel satın alma dürtüsü ve çevrim içi itkisel satın alma davranışını olumlu yönde etkilerken, itkisel satın alma dürtüsü de çevrim içi itkisel satın alma davranışını olumlu yönde etkilemektedir.

\footnotetext{
ABSTRACT

The main purpose of the study is to evaluate the effects of electronic service quality dimensions, urge to buy impulsively and hedonic browsing variables on online impulse buying behavior. The data were collected using a structured questionnaire from 18 years and older consumers. A total of 338 valid data obtained. As a result of the analysis, it is seen that design and security / privacy of electronic service quality dimensions have a positive effect on urge to buy impulsively. Likewise, hedonic browsing on the internet positively affects both the urge to buy impulsively and online impulsive buying behavior. Finally, urge to buy impulsively positively affects the online impulse buying behavior.
} 


\section{GİRIŞ̧}

Her geçen gün ürünlerin yaşam evrelerinin kısalması, tüketim hızının çılgın boyutlara ulaşması ve 21. yüzyılda farklı kültürel değerlerle bezenseler dahi, toplumların "tüketim toplumu" olarak adlandırılması, tüketicilerde itkisel satın alma davranışının görülme sıklığının da artmasına neden olabilmektedir. Kazempour ve Lotfizadeh (2017: 12) Amerika'da toplam mağaza satışlarının yaklaşık olarak \%80'lik payının itkisel satın alma davranışından oluştuğunu belirtmişlerdir. İtkisel satın alma, tüketicilerin ürünü görür görmez satın alma arzusuna sahip olması ve düşünmeden, çok kısa bir süre diliminde de satın alma eylemine geçmesi olarak tanımlanmaktadır (Rook ve Fisher, 1995: 312; Hausman, 2000: 404). Beatty ve Ferrell (1998: 170) tüketicinin herhangi özel bir ürünü satın alma planı ve niyeti olmamasına rağmen, karşı konulamaz içgüdüyle satın alma eylemini gerçekleştirmesi durumunu itkisel satın alma davranışı olarak adlandırmışlardır. Günümüzde, internet teknolojlerinin gelişmesi, buna bağlı olarak elektronik ticaretin büyümesi ve internetin bireylerin hayatlarının bir parçası olması itkisel satın alma kavramının çevrim içi ortama taşınmasına neden olmuştur.

Çevrim içi itkisel satın alma, çevrim içi ortamda bireylerin alışveriş yapma niyeti olmadan ani, plansız şekilde güdüleri ile hareket etmeleri olarak tanımlanmaktadır (Sohn ve Lee, 2017: 345). Bu kavram, tüketicilerin değişen yaşam tarzlarını yansıtan bir fenomen halini almıştır.Tüketicilerin çevrim içi ortamda istenilen ürüne hızlı ve kolay ulaşımı, sosyal baskıyla karşılaşmamaları, fiziksel ortamlarda yapılan alışverişten farklı olarak taşıma sorunları ile uğraşmamaları gibi faktörler bu olguyu tetiklemektedir (Chan ve Zhang, 2015: 45). Liu vd. (2013: 829) çevrim içi ortamda alışveriş yapanların yaklaşık olarak \% 40’nın itkisel satın alma davranışı sergilediğini belirtmişlerdir. Eroğlu vd. (2001: 177) tüketiciler için itkisel satın alma bağlamında çevrim içi ortamın sınırlı çalışma saatleri, uygunsuz mağaza konumu, sosyal baskı gibi kısıtlamalara tabi olmadığ alışverişten daha fazla itkisel satın alma davranışını mümkün kıldığını ileri sürmüşlerdir. Çevrim içi itkisel satın alma davranışının yaygınlaşmasına rağmen, tüketicilerin farklı çevresel faktörler altında alışılagelmiş hareketlerin dışına çıkmaları, karar verme süreçlerinin tahmin edilmesini de zorlaştırmaktadır (Akram vd., 2018: 3).

Literatüre bakıldığında, temel olarak çevrim içi itkisel satın alma davranışlarının içsel ve dışsal öncüller olarak adlandırılan faktörlerle incelendiği görülmektedir. İçsel öncüller, tüketicilerin kişilik özellikleri, sahip oldukları dürtüler, duygusal durumları, demografik özellikleri vb. olarak kabul edilirken, bahsedilen içsel öncüllerin aynı zamanda tüketicilerin çevrim içi itkisel satın alma eğilimlerini ve dürtülerini de etkilediği düşünülmektedir (Dawson ve Kim, 2009: 23). İçsel öncüllerin, tüketicilerin itkisel satın alma eğilimlerinin düzeylerini anlamamızı sağlayacağını ve yüksek düzeyde eğilim gösteren tüketicilerin internet sitesi özellikleri, promosyon, reklam vb. gibi uyarıcılar aracılığıyla itkisel satın alma davranışında bulunma olasılığının da yüksek olduğuna dair sonuçlara ulaşan araştırmacılar (Jones vd. 2003: 506; Madhavaram, 2004: 61; Styven vd., 2017: 418 ) da mevcuttur. Dişsal öncüller (Ürünlerin özellikleri ve alternatiflerin durumu, internet sitesi karakteristik özellikleri, kalite boyutları vb.) pazarlama ve tasarım uzmanlarının tüketicilerin satın alma davranışlarını etkileyebilmek için oluşturulan ya da yerleştirilen uyaranlardır (Dawson ve Kim, 2009: 24). Verhagen ve Dolen (2011), Park vd. (2011), Chan vd. (2017) ve Akram vd. (2017) gibi araştırmacılar internet sitelerinin farklı ölçeklere ait kalite boyutlarını kullanarak çevrim içi itkisel satın alma üzerindeki etkilerini araştırmışlardır. Tasarım ya da görsellik, gizlilik, 
güven, etkileşim, kişiselleştirme gibi elektronik hizmet kalite boyutlarının tüketicilerin çevrim içi itkisel satın alma davranışı sergileme olasılığını artırdığını ifade etmişlerdir. Literatürde, çevrim içi itkisel satın alma davranışları dışsal öncüllerden olan elektronik hizmet kalite boyutları ile açıklanmaya çalışılırken, itkisel satın alma davranışın temelini oluşturan itkisel satın alma dürtüsü ile bahsi geçen kalite boyutları ilişkisini inceleyen çalışmalar (Wells vd., 2011; Liu vd., 2013; Habib ve Qayyum, 2017) sınırlıdır. Sonuç olarak, satın alma davranışının gerçekleşebilmesi için davranışı gerçekleştirecek olan bireylerin öncelikle anlık ve dürtüsel olarak bir şeyler hissetmesi gerekmektedir (Beatty ve Ferrell, 1998: 170).

İnternette hedonik gezinme, tüketicilerin satın alma amacı olmadan eğlence amaçlı olarak alışveriş sağlanan internet sitelerinde zaman harcamalarıdır (Shirmohammadi vd., 2015: 282). Park vd. (2012: 1584), Habib ve Qayyum (2017) gibi sınırlı araştırmada, internette hedonik gezinmeden keyif alan kişinin daha fazla zaman geçireceği için çevrim içi ortamda itkisel satın alma davranışı gösterme olasılığının artacağını belirtmiştir. Dolayısıyla, araştırmada çevrim içi itkisel satın almanın içsel öncüllerinden dürtünün tüketicilerin internette hedonik gezinmesi ile ilişkisi olabileceği düşünülmüş ve araştırma modeline eklenmiştir.

Çalışmanın literatür kısmı, elektronik hizmet kalite boyutları, internette hedonik gezinme, itkisel satın alma dürtüsü ve çevrim içi itkisel satın alma davranışından oluşmaktadır. Literatür incelemelerinden sonra oluşturulan araştırma modeli doğrultusunda, elektronik hizmet kalite unsurlarının ve internette hedonik gezinmenin; itkisel satın alma dürtüsü ve yine internette hedonik gezinme ve itkisel satın alma dürtüsünün, çevrim içi itkisel satın alma davranışı üzerindeki etkileri incelenecektir.

\section{LITERATÜR}

\subsection{Elektronik Hizmet Kalite Boyutları}

İnternet teknolojisinin hızlı bir şekilde gelişmesi ve yaygınlaşması, çevrim içi platformlar arasında yoğun rekabete yol açmaktadır. Bu durumda çevrim içi alışveriş rekabetinin birincil avantaj kaynağı elektronik hizmet kalitesi durumuna gelmektedir. Elektronik hizmet kalitesinin derecesi, müşterilerle oluşturulan ilişki düzeyini ve süresini, sadakat boyutunu ve en nihayetinde de işletmelerin karlılık düzeyini doğrudan etkilemektedir (Theodosio vd., 2019: 53). Çevrim içi hizmet veren işletmeler aynı zamanda e-hizmet kalitesini verimlilik düzeylerini ölçmek için kullanmaktadırlar. Çevrim içi ortamlarda müşterilerin satın almak istedikleri ürünlerin çeşitliliği, ihtiyaçları karşılama derecesi, ürünlerle ilgili sunulan bilgiler ve satın alma ve satın alma sonrası teslimat işlemlerinin etkinliği işletmelerin verimliliklerini etkilemektedir (Zeithaml vd., 2000: 11).

Günümüzde araştırmacılar elektronik hizmet kalite boyutlarının neler olduğu konusunda kesin bir fikir birliği oluşturamasalar da sistematik olarak araştırmaların çoğunda yer alan boyutlar kullanım kolaylığı, bilginin niteliği, tasarım, güven, güvenlik/gizlilik ve etkileşim ve kişiselleştirmedir (Parasuraman vd., 2002: 371; Barnes ve Vidgen 2003: 124; Wolfinbarger ve Gilly 2003: 196).

Kullanım kolaylığı genellikle çevrim içi ortamlarda kullanılabilirlik olarak da adlandırılmaktadır İnternet sitesinin arama işlevleri, indirme hızı, genel tasarım ve organizasyona bağlı işlevselliği kullanılabilirliği etkileyen temel unsurlar arasındadır (Parasuraman vd., 2002: 364). Ayrica internet sitesine yeni bilgilerin eklenmesi, detaylı arama imkanlarının geliştirilmesi de kullanım kolaylığı unsurlarındandır. Shirmohammadi vd. 
(2015: 287) kullanım kolaylığının çevrim içi ortamda bireylerin olumlu duyguları üzerinde anlamlı etkisinin olduğunu, bu etkinin de itkisel satın alma dürtüsünü harekete geçirdiğini ifade etmişlerdir. Liu vd. (2013: 834) çevrim içi ortamda bireylerin anlık hissettiği hazzın internet sitelerinin kullanım kolaylığı ile ilgili olduğunu ve bu etkinin itkisel satın alma dürtüsü üzerinde olumlu etkisinin varlığından söz etmişlerdir. İlgili literatür bağlamında oluşturulan araştırma hipotezi aşağıdaki gibidir;

$\mathrm{H}_{1}$ : Kullanım kolaylığ

Etkileşim ve kişiselleştirme tüketicilerin marka ile ayrıcalıklı bir ilişkiye sahip olarak, kendi ihtiyaçlarına göre ürün ve hizmetleri gerçek zamanlı şekilde uyarlamaları anlamına gelmektedir (Ho ve Tam, 2005: 100). Tüketiciler, eş zamanlı etkileşimleri sayesinde kendilerine en iyi değeri sağlayacak ürünü elde ederek tatmin olmuş olacaklardır. Ayrıca, tükecilerin tercihlerine değer veren ve önemseyen işletmeler de tüketicilerin kendileri hakkında olumlu tutuma sahip olmalarını sağlayacaklardır (Bitner vd., 2000: 52). Yang ve Young (2009: 130) kişiselleştirmenin çevrim içi ortamda giysi alma konusunda tüketicilerin karar almasını olumlu yönde etkilediğini belirtirken, Bressolles vd. (2007: 39) araştırmasında tüketicilerin tatmini ile elektronik hizmet kalite boyutlarının ilişkisini incelemeye çalışmıştır. İlgili literatür bağlamında oluşturulan araştırma hipotezi aşağıdaki gibidir;

$\mathrm{H}_{2}$ : Etkileşim ve kişiselleştirme, itkisel satın alma dürtüsünü olumlu yönde etkilemektedir.

Güven, hizmet sağlayıcıların tüketiciler için vaat ettiklerini (ürünün doğru şekilde sunulması, hizmet sözleşme şartlarına uyulması, hatasız teslimat vb.) kusursuz şekilde yerine getirmesi olarak tanımlanmaktadır (Parasuraman vd., 2002: 364). Elliott ve Speck (2005: 48) internet sitesi unsurlarından bilgi sağlama, güven ve eğlencenin tüketicilerin çevrim içi ortamda alışveriş yapma tutumlarını etkilediğini belirtirken, Wells vd. (2011: 46) güven ve tasarımın çevrim içi itkisel satın alma üzerindeki etkisini araştırmışlardır. İlgili literatür bağlamında oluşturulan araştırma hipotezi aşağıdaki gibidir;

$\mathrm{H}_{3}$ : Güven, itkisel satın alma dürtüsünü olumlu yönde etkilemektedir.

Tasarım, internet sitesinin biçimsel özellikleri (grafikler, kullanılan renkler, metinlerin boyutu, arama konfigürasyonları vb.) ile ilgilidir (Dawson ve Kim, 2009: 23). Literatürde birçok araştırmacının (Liu vd., 2013: 834; Türkyılmaz vd., 2015: 104; Ling ve Yazdanifard, 2015: 29) internet sitelerinin tasarımlarının kullanıcıların itkisel satın alma güdüsünü olumlu yönde etkilediğine dair çalışmaları mevcuttur. İlgili literatür bağlamında oluşturulan araştırma hipotezi aşağıdaki gibidir;

$\mathrm{H}_{4}$ : Tasarım, itkisel satın alma dürtüsünü olumlu yönde etkilemektedir.

Güvenlik unsuru, çevrim içi ortamda alışveriş yapan bireylerin sahtekarlıklardan ve maddi kayıplardan korunması anlamına gelmektedir. Gizlilik ise, internet sitelerinin tüketiciler hakkında elde ettikleri bilgilerin korunması, başkaları ile paylaşılmaması ya da başkalarına satılmaması ile ilgilidir (Parasuraman vd., 2002: 364; Bressolles vd., 2007: 39). Taylor vd. (2010: 9) ve Chakraborty (2017: 1311) yaptıkları araştırmalarda elektronik hizmet kalite unsurlarından olan güvenlik ve gizliliğin itkisel satın almayı olumlu yönde etkilediğini ifade etmişlerdir. İlgili literatür bağlamında oluşturulan araştırma hipotezi aşağıdaki gibidir; $\mathrm{H}_{5}$ : Güvenlik ve gizlilik, itkisel satın alma dürtüsünü olumlu yönde etkilemektedir.

Tüketicilerin çevrim içi ortamda satın almak istedikleri ürünlerle fiziksel temasının mümkün olmaması, sunulan bilginin niteliğinin önemini artırmaktadır. Bilginin niteliği unsuru, internet kullanıcılarının satış sözleşmesi, ürün ve hizmetler hakkındaki teknik ya da ticari verileri 
kapsamaktadır (Bressolles vd., 2007: 39). Elliott ve Speck (2005: 48) bilgi sağlamanın tüketicilerin çevrim içi ortamda alışveriş yapma tutumlarını etkilediğini belirtirken, Liu vd. (2013: 834), Chakraborty (2017: 1311), Hasim vd. (2019: 223) gibi araştırmacilar internet sitesi kalitesinin itkisel satın alma dürtüsü ve çevrim içi itkisel satın alma davranışı üzerindeki ilişkileri incelerken bilginin niteliği unsurundan da yararlanmışlardır. İlgili literatür bağlamında oluşturulan araştırma hipotezi aşağıdaki gibidir;

$\mathrm{H}_{6}$ : Bilginin niteliği, itkisel satın alma dürtüsünü olumlu yönde etkilemektedir.

\subsection{Hedonik Gezinme}

Çevrim içi alışverişin ilk aşaması, tüketicilere satın alacakları ürünleri değerlendirmelerini sağlayan, onlara farklı firsatlar sunarak eğlenceli vakit geçirmelerini sağlayan internet sitelerinde gezinmeleridir (Rowley, 2002: 369). Tüketici davranışları açısından hedonik ve faydacı olmak üzere iki tür internette gezinme faaliyeti vardır. Faydacı gezinme, tüketiciler için hedefe yönelik bir davranıştır ve tüketiciler hedeflerine ulaşılırken internet sitelerinde gezinme davranışlarını durdururlar. Tüketiciler internette gezinirken fayda amacı güttükleri için kendileri için en az maliyetli ve en fazla değeri sağlayacak ürünü satın alarak satın alma riskini de azaltmak istemektedirler (Overby ve Lee, 2006: 1161). Hedonik gezinmede ise, tüketiciler ürünlerin satın alma işleminin gerçekleşip gerçekleşmemesinden bağımsız olarak alışverişin daha keyifli yönlerine odaklanırlar (Park vd., 2012: 1584).

İtkisel satın alma davranışı ile ilgili araştırmalarda daha çok hedonik yönün ele alınmasının temel sebebi, itkisel satın almanın doğasından kaynaklanmaktadır. İtkisel satın almada bireyler anlık, plansız ve güdüleriyle hareket ederlerken; hedonik boyutta da tüketici deneyimsel ve içgüdüsel ihtiyaçlarını karşılamak için zevk, eğlence veren tüketim peşindedir (Hanzee vd., 2011: 1637). Huang (2005: 850) yaptığ1 araştırmada tüketicilerin internette alışveriş yaparlarken farklı duygular içerisinde olabileceklerini ve çevrim içi ortamların tüketicilere haz yaratan, keşif yapmalarını teşvik edici olmaları halinde daha fazla verimli olabileceğini ifade etmiştir. Verplanken ve Herabadi (2001: 572), itkisel satın almanın olabilmesi için bireylerde heyecan ve haz duygusunun olması gerektiğini, bunun da alışveriş ortamında daha fazla gezinme ile mümkün olabileceğini belirtmişlerdir. Dolayısıyla, internette hedonik gezinmeden keyif alan kişinin daha fazla zaman geçireceği için çevrim içi ortamda itkisel satın alma davranışı gösterme olasılığının artacağı düşünülmektedir (Park vd., 2012: 1584). Novak vd. (2003: 13) tüketiciler için çevrim içi ortamda eğlence için geçirilen zamanın, amaca yönelik olarak geçirilen zamandan daha fazla olduğunu ve hedonik boyutun tüketiciler açısından öneminin arttığını ifade etmiştir. Araştırmacıların çoğu (Park vd., 2012: 1588; Rezai vd., 2016: 74; Dewi vd., 2017: 87;) internette hedonik gezinmenin çevrim içi itkisel satın alma davranışını olumlu yönde etkilediğini ifade ederken, araştırmalarında internette hedonik gezinme ve itkisel satın alma dürtüsü ilişkisini inceleyen Habiba ve Qayyumb (2017: 10), Zhang vd. (2018: 13), Verhagen ve Dolen (2011: ) gibi araştırmacilar da internette hedonik gezinmenin bireylerin itkisel satın alma dürtüsü üzerinde olumlu etkisinin olduğunu ifade etmişlerdir. İlgili literatür bağlamında oluşturulan araştırma hipotezleri aşağıdaki gibidir;

$\mathrm{H}_{7}$ : İnternette hedonik gezinme, itkisel satın alma dürtüsünü olumlu yönde etkilemektedir.

$\mathrm{H}_{8}$ : İnternette hedonik gezinme, çevrim içi itkisel satın alma davranışını olumlu yönde etkilemektedir. 


\section{3. İtkisel Satın Alma Dürtüsü ve Çevrim içi İtkisel Satın Alma}

İtkisel satın alma, bireylerin arzuları ve bu arzuların tetiklediği davranışlar olmak üzere iki kısıma ayrılmaktadır Rook (1987: 193). Satın alma davranışının gerçekleşebilmesi için davranışı gerçekleştirecek olan bireylerin öncelikle anlık ve dürtüsel olarak bir şeyler hissetmesi gerekmektedir. İtkisel satın alma dürtüsü, bireyler tarafından dürtüsel olarak karşılaşılan güçlü arzu durumunu ifade etmektedir. Bu karşı konulması ya da dayanılması zor olarak nitelendirilen istekle birlikte, birey düşünmeden anlık olarak itkisel satın alma davranışını gerçekleştirmektedir (Beatty ve Ferrell, 1998: 170). Bireyler, her itkisel satın alma dürtüsüne sahip oldukları durumlarda bu dürtüyü satın alma davranışına çevirmeseler de, çoğu durumda dürtü etkisi ile birey harekete geçebilmektedir (Rook ve Fisher, 1995: 307). Kacen ve Lee (2002:163) bireylerin sahip oldukları güçlü dürtünün, ürün hakkında bilgi toplama ya da alternatifleri ile karşılaştırma yapmayı engelleyerek satın alma karar sürecini kısalttığını belirtmişlerdir.

İtkisel satın alma dürtüsü, bireylerin önceden planlanmadıkları dolayısıyla da doğrudan ihtiyaç duyacakları ürünlerin aksine, onlara anlık neşe ve mutluluk, daha sonra da tatmin duygusu yaşatacak ürünlerin satın alınmasına neden olmaktadır (Verhagen ve Dolen, 2011: 321). Dolayısıyla, bireylerin psikolojik sorunlarından kaçmak ya da yüzleşmek istemedikleri durumlarda da itkisel satın alma dürtüsü sıklıkla ortaya çıkabilmektedir. Bireyler, psikolojik sorunlarını tetikleyecek kızgınlık, üzüntü ve pişmanlık durumlarında kendilerini mutlu edecek ve bir ödül olarak gördükleri ürünlere itkisel satın alma dürtüsü ile yönelebilmektedirler (Ling ve Yazdanifard, 2015: 30). Bununla birlikte, Trandafilovic vd. (2013) itkisel satın alma sürecinin son derece karmaşı ve birey açısından tatmin ve suçluluk duyguları arasında gidip gelen çetrefilli bir durum olduğu için itkisel satın alma dürtüsünün her zaman itkisel satın alma davranışı ile son bulmadığını belirtmişlerdir.

Tüketici karar verme süreci genel olarak müşterilerin akılcı bir faaliyet içerisinde olduğu, ihtiyaç duyulan ürünü belirlemek, değerlendirmek ve en uygun olanını seçmek için alternatifleri karşılaştırdığı eylemler dizisi olarak tanımlanmaktadır (Haubl ve Trifts, 2000: 7). Ancak günümüzde internet teknolojisinin gelişmesi, akıllı telefon uygulamalarının artması ve tüketicilerin farklı çevresel faktörler (referans grupları, sosyal medya ortamı, reklamlar, psikolojik ve durumsal faktörler vb.) tarafindan etki altında kalması sebebiyle alışıla gelmiş durumların dışına çıkarak çevrim içi itkisel satın alma davranışı sergilediği gözlemlenmektedir (Chen vd., 2016: 64). Sharma vd. (2010: 276) çevrim içi itkisel satın alma esnasında, tüketicilerin dürtülerinin yönlendirmesi ve duygularıyla hareket ettiklerini, düşük bilişsel kontrol sergilediklerini ve kendileri için fazla sayıda ilgi çekici ve alternatifli nesneler gördüklerinde alışverişin finansal ve diğer yönlerini göz önünde bulundurmadıklarını belirtmiştir. Bu açıdan bakıldığında çevrim içi ortamda itkisel satın alma davranışı sergileyen bireylerin, fiziksel ortamda satın alma davranışı sergileyenlerden daha fazla güdüleri ile hareket etme durumları olduğu söylenebilir (Park vd.,2012: 1586; Verhagen ve Dolan, 2011: 321). Chan vd. (2017) internet üzerinden alışveriş yapmanın tüketicileri fiziksel pazarlarda karşılaşılan potansiyel kısıtlamalardan (zorlu hava koşulları, ulaşım sorunları, taşıma vb.) kurtararak çevrim içi itkisel satın alma davranışı olasılığını artırdığını belirtmişlerdir. Verhagen ve Dolen (2011) ise, sosyal baskının az olması, kolayca satın alma işleminin yapılabilmesi, hızlı teslimat ve alternatiflerin fazlalığı gibi nedenlerle tüketicilerin çevrim içi ortamda daha fazla itkisel satın alma davranışında bulunabileceğini ifade etmişlerdir. Çevrim içi itkisel satın alma ile ilgili bir diğer nokta ise, gerçekleşen ödeme işlemlerinin yapısı gereği 
tüketicilere daha fazla para harcatabilmesidir. Bunun sebebi, alışveriş yapan tüketicilerin fiziksel ortamda yapılan alışverişten farklı olarak, çevrim içi ortamda gerçekten de para harciyor hissine kapılmamasıdır (Dittmar vd., 2004: 443).

Literatürde itkisel satın alma dürtüsü ve itkisel satın alma davranışı ile ilgili çalışmalara bakıldığında daha çok alışveriş merkezleri veya mağazalarda ortaya çıkan durumsal faktörlerle ilişkisinin incelendiği görülmektedir. Bunun sebebi, bireylerin ürünlere karşı olan fiziksel yakınlığının itkisel dürtüyü harekete geçirerek itkisel satın alma davranışına neden olacağı düşüncesidir (Beatty ve Ferrell, 1995: 172). Durumsal faktörler, bireyi etkileyen çevresel (satış personeli, promosyonlar, mağazaların fiziksel ortamları, ürünlerin kendine has özellikleri v.b.) ve kişisel faktörler (alışverişe harcanan zaman ve para, gelir durumu vb.) olarak ele alınmaktadır (Dholakia, 2000: 961). Bu çalışmaların çoğunda, mağaza fiziksel ortamının (mağazalarda çalan fon müziği, ürünlerin raf düzenlemesi, koku, 1ş1k vb.) bireylerde itkisel satın alma dürtüsünü hareket geçirdiği, itkisel satın alma dürtüsüne sahip bireylerin de itkisel satın alma davranışına yöneldiği belirtilmektedir ( Martinez vd., 2010: 284; Parsad vd., 2017: 18). Bazı araştırmacılar (Jones vd., 2003: 510; Dholakia, 2000: 978; Mohan, 2013: 19) da ürün ve ürün özelliklerinin itkisel satın alma dürtüsünü hareket geçirdiğini savunurken, bazıları (Parboteeah, 2005: 37; Yu ve Bastin, 2010: 112; Mohan vd., 2013: 19) ise satış personeli etkisinin ve promosyonların bireylerin itkisel satın alma güdüsü ile birlikte itkisel satın alma davranışına yönlendirdiğini ifade etmişlerdir.

Araştırmacıların az sayıda çalışmada itkisel satın alma dürtüsü ve çevrim içi itkisel satın alma ilişkisini ortaya koymaya çalıştıkları görülmektedir. Verhagen ve Dolen (2011: 325) yaptıkları çalışmalarında, bireylerin olumlu ya da olumsuz halinin itkisel satın alma dürtüsünü, itkisel satın alma dürtüsünün de çevrim içi itkisel satın alma davranışını anlamlı şekilde etkilediğini ifade etmişlerdir. Chan vd. (2017: 7) durumsal faktörlerin, internet sitelerinin karakteristik özelliklerinin ve tüketicilerin kişisel özelliklerinin itkisel satın alma dürtüsünü, itkisel satın alma dürtüsünün de çevrim içi itkisel satın alma davranışını olumlu yönde etkilediğini belirtmişlerdir. Shirmohammadi vd. (2015: 287) araştırmalarında internette hedonik gezinmenin itkisel satın alma dürtüsünü etkilediğini, aynı şekilde itkisel satın alma dürtüsünün de itkisel satın alma davranışını olumlu şekilde etkilediğini ifade etmişlerdir. İlgili literatür bağlamında oluşturulan araştırma hipotezi aşağıdaki gibidir;

$\mathrm{H}_{9}$ : İtkisel satın alma dürtüsü, çevrim içi itkisel satın alma davranışını olumlu yönde etkilemektedir.

\section{METODOLOJí}

\subsection{Araştırmanın Amacı}

Araştırmanın amacı, elektronik hizmet kalite boyutlarının ve internette hedonik gezinmenin itkisel satın alma dürtüsü ve bireylerin çevrim içi itkisel satın alma davranışları üzerindeki etkisini ortaya koyabilmektir.

\subsection{Araştırma Modeli}

Araştırma modeli bireylerin alışveriş yaptıkları internet sitelerinin elektronik hizmet kalite boyutlarını oluşturan kolay kullanım, bilginin niteliği, tasarım, güven, güvenlik/gizlilik, etkileşim ve kişiselleştirme, itkisel satınalma dürtüsü, hedonik gezinme ve son olarak çevrim içi itkisel satın alma davranışı faktörlerinden oluşmaktadır. Araştırma modeli Şekil 1'de gösterilmektedir. 


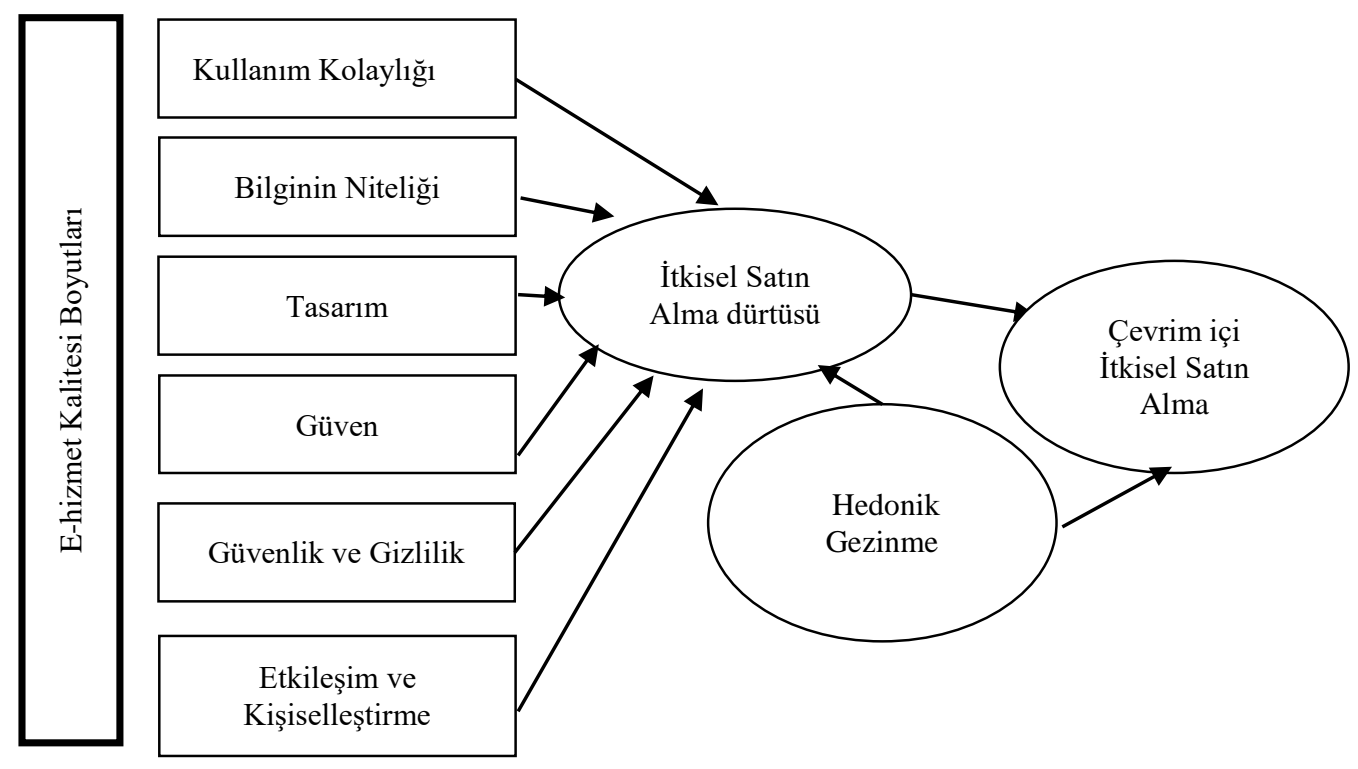

Şekil 1. Araştırma Modeli

\subsection{Araştırmanın Ana kütlesi, Örneklem ve Verilerin Toplanması}

Araştırma evreni, ülkemizde yaşayan 18 yaşından büyük bireylerden oluşmaktadır. Anakütlenin sayısının fazlaca büyük olduğu durumlar için kolayda örnekleme yöntemi kullanılabilmektedir (Nakip, 2003: 183).

Veri toplama amaciyla hazırlanan form yüzyüze anketlerle 16.12.2019- 23.12.2019 tarihleri arasında Uşak'ta yaşayan bireylere uygulanmıştır. $\mathrm{Bu}$ bağlamda 350 bireyden veri toplanmıştır. Eksik veri ve hatalı cevaplamaya bağlı problemler nedeniyle 12 adet anket formu veri setinden çıkartılmış ve kalan 338 adet veri ile araştırmanın analizleri gerçekleştirilmiştir. Beşli likert (1-Kesinlikle Katılmıyorum, 5-Kesinlikle Katılıyorum) tipinde hazırlanan veri seti, Amos 23.0 ve SPSS 21.0 paket programları kullanılarak analiz edilmiştir.

Araştırma modelinde yer alan değişkenlerden elektronik hizmet kalite boyutunu oluşturan kullanım kolaylığı değişkenine ait iki ifade, bilginin niteliğine ilişkin üç ifade, tasarım değişkenine ait dört ifade, güven değişkenine ait iki ifade, güvenlik/gizlilik değişkenine ait beş ifade ve son olarak etkileşim ve kişiselleştirme değişkenine ait iki ifade olmak üzere toplam 18 ifade Bressolles v.d. (2007) çalışmasından uyarlanmıştır. Çevrim içi dürtüsel satın almaya ilişkin beş ifade Rook ve Fisher (1995), satın alma dürtüsüne ait dört ifade ve internette gezinmeye ait üç ifade Verhagen ve Van Dolen (2011) çalışmalarından uyarlanmıştır. 


\section{ARAŞTIRMANIN BULGULARI}

\subsection{Tanımlayıcı İstatistiki Bulgular}

Araştırmada örnek kütleyi oluşturan bireylerin demografik özelliklerine ait bulgular Tablo 1 'de yer almaktadir.

Tablo 1. Katılımcıların Demografik Özellikleri

\begin{tabular}{|c|c|c|c|}
\hline Demografik Özellikler & & Frekans & $\%$ \\
\hline \multirow{2}{*}{ Cinsiyet } & Kadın & 180 & 53.2 \\
\hline & Erkek & 158 & 46.8 \\
\hline \multirow{4}{*}{ Yaş } & TOPLAM & 338 & 100 \\
\hline & $18-30$ & 162 & 48.0 \\
\hline & $31-44$ & 100 & 29.5 \\
\hline & 45 ve üzeri & 76 & 22.5 \\
\hline & TOPLAM & 338 & 100 \\
\hline \multirow{5}{*}{ Eğitim Düzeyi } & İlköğretim & 11 & 3.2 \\
\hline & Lise & 156 & 46.0 \\
\hline & Önlisans & 61 & 18.0 \\
\hline & Lisans & 97 & 28.7 \\
\hline & Lisansüstü & 13 & 4.1 \\
\hline \multirow{6}{*}{ Aylık Gelir Düzeyi } & TOPLAM & 338 & 100 \\
\hline & 2020 TL ve alt1 & 158 & 46.7 \\
\hline & $2021-3600 \mathrm{TL}$ & 41 & 12.1 \\
\hline & $3601-4800 \mathrm{TL}$ & 116 & 34.3 \\
\hline & 4801 TL ve üzeri & 23 & 6.9 \\
\hline & TOPLAM & 338 & 100 \\
\hline
\end{tabular}

Tablo 1, araştırmada yer alan bireylerin \%53.2'sinin kadınlardan ve \%46.8'inin de erkeklerden oluştuğunu göstermektedir. Katılımcıların çoğunluğu (\%48.0) 18-30 yaş arasında iken, 156 katılımcı sayısı ile lise mezunları çoğunluktadır. Araştırmaya katılan bireylerin \%46.7'sinin asgari ücret ve altında, \%6.9'unun ise 4,801 TL ve üzeri gelire sahip olduğu dikkat çeken bulgulardandır.

\subsection{Yorumlayıcı İstatistiki Bulgular}

\subsubsection{Açımlayıcı Faktör Analizi (AFA) Bulguları}

Anket formlarından elde edilen veri setinin açımlayıcı faktör analizine uygunluğunu test etmek için KMO (Kaiser-Meyer-Olkin) testi ve Bartlett's Sphericity küresellik testleri kullanılmaktadır (Punch, 2005: 124; Kalaycı, 2010:322). Bu kapsamda araştırma modelinde yer alan elektronik hizmet kalite boyutunu oluşturan 17 madde olmak üzere kullanım kolaylığı (KK1-KK2), etkileşim ve kişiselleştirme (EK1-EK2), güven (G1-G2), tasarım (T1T4), güvenlik/gizlilik (GG1-GG4), bilginin niteliği (BN1-BN3), itkisel satın alma dürtüsü (S1-S4), hedonik gezinme (HG1-HG3) ve çevrim içi itkisel satın alma (ÇİS1-ÇİS5) olmak üzere toplam 29 madde için faktör analizi gerçekleştirilmiştir. Açımlayıcı faktör analizinden elde edilen sonuçlar Tablo 2'de sunulmuştur.

Tablo 2. Açımlayıcı Faktör Analizi Sonucu

\begin{tabular}{|lcccc|}
\hline Değişkenler & Ortalama & S. Sapma & Faktör Yükü & $\boldsymbol{\alpha}$ \\
\hline Kullanım Kolaylı̆̆ı & & & & \\
\hline KK1 & 4.02 & 0.929 & 0.877 & 0.892 \\
\hline
\end{tabular}


KARAHAN

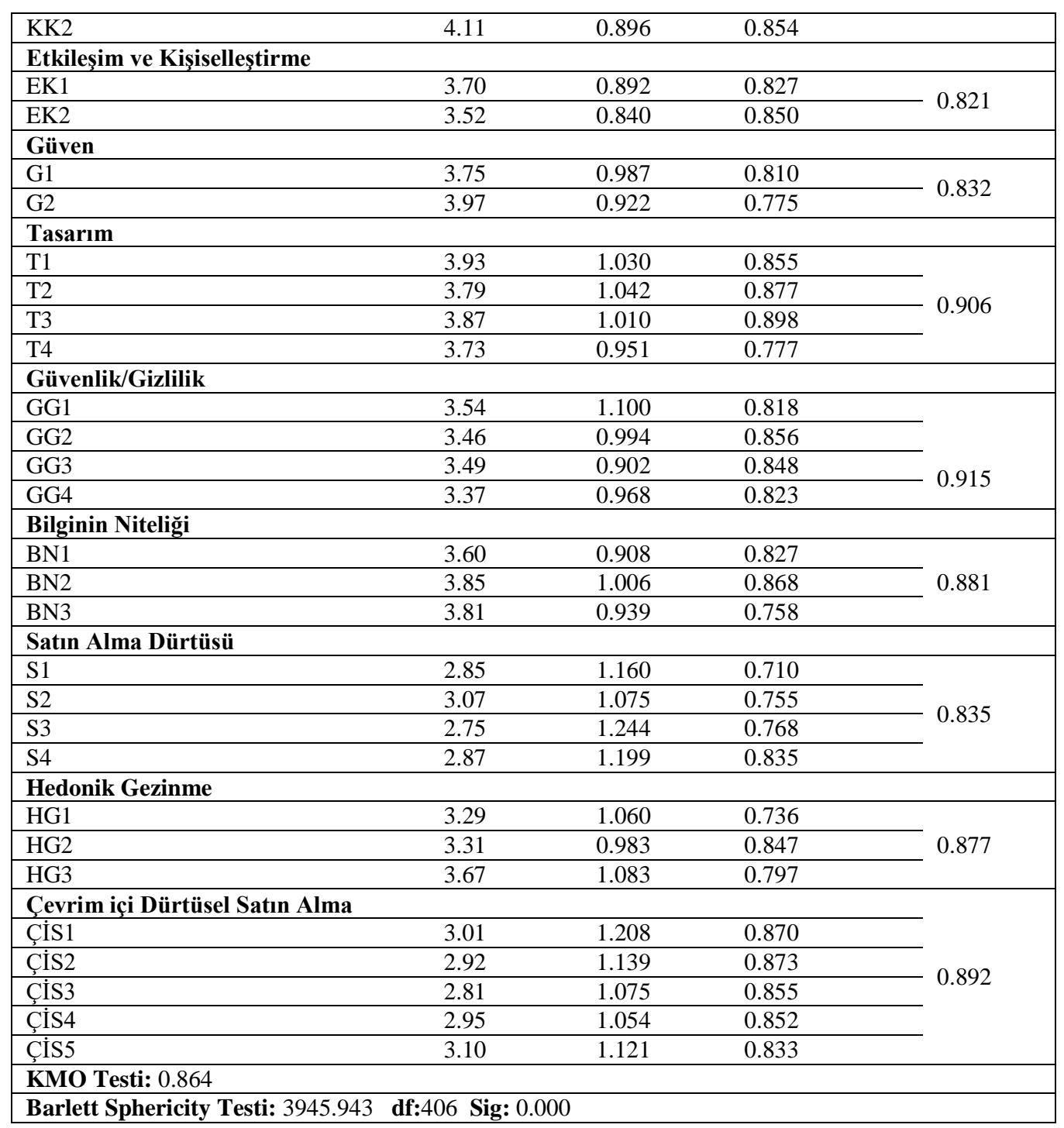

Tablo 2'de görüldüğü üzere, faktörlerin KMO değeri \%0.864 iken Barlett's Sphericity testi değeri $\mathrm{p}<0.001$ 'dir. Dolayısıyla, elde edilen verilerin faktör analizi için kabul edilebilir olduğu söylenebilir. Açımlayıcı faktör analizi sonucunda kullanım kolaylığı faktörüne ait yüklerin 0.854-0.877 arasında, etkileşim ve kişiselleştirme faktörüne ait yüklerin 0.827-0.850 arasında, güven faktörüne ait yüklerin $0.775-0.810$ arasında, tasarım faktörüne ait yüklerin 0.777-0.898 arasında, bilginin niteliği faktörüne ait yüklerin $0.758-0.868$, güvenlik/gizlilik faktörüne ait yüklerin 0.818-0.856 arasında itkisel satın alma dürtüsü faktörüne ait yüklerin ise $0.710-0.835$ arasında, hedonik gezinme faktörüne ait yüklerin $0.736-0.847$ arasında ve çevrim içi itkisel satın alma faktörüne ait yüklerin ise 0.833-0.873 arasında değerlerde olduğu 
görülmektedir. Dokuz değişken toplam varyansın \%83.64'ünü açıklamaktadır. Değişkenlerin güvenirlilik katsayıları, içsel tutarlığın sağlandığı göstermektedir.

\subsubsection{Doğrulayıcı Faktör Analizi (DFA) Bulguları}

Açımlayıcı faktör analizi sonuçları elde edildikten sonra araştırma modelinin güvenirliğini ve geçerliliği test etmek için doğrulayıcı faktör analizi (DFA) gerçekleştirilmiştir. Tablo 3'de standardize edilmiş yol katsayıları (SEYK), t değerleri, yapı güvenirliliği (composite reliability-CR), ortalama açıklanan varyans (average variance extracted-AVE) ve Maksimum Paylaşılan Varyansın Karesi (Maximum Squared Variance) MSV değerleri gösterilmektedir.

Tablo 3. Doğrulayıcı Faktör Analizi Sonuçları

\begin{tabular}{|c|c|c|c|c|c|}
\hline Faktörler & SEYK & t değeri & CR & AVE & MSV \\
\hline \multicolumn{6}{|c|}{ Kullanım Kolaylığı } \\
\hline KK1 & 0.90 & & \multirow{2}{*}{0.80} & \multirow{2}{*}{0.79} & \multirow{2}{*}{0.33} \\
\hline KK2 & 0.88 & 12.09 & & & \\
\hline \multicolumn{6}{|c|}{ Etkileşim ve Kişiselleştirme } \\
\hline EK1 & 0.87 & & \multirow{2}{*}{0.82} & \multirow{2}{*}{0.70} & \multirow{2}{*}{0.27} \\
\hline EK2 & 0.79 & 8.87 & & & \\
\hline \multicolumn{6}{|l|}{ Güven } \\
\hline G1 & 0.75 & & \multirow{2}{*}{0.84} & \multirow[b]{2}{*}{0.73} & \multirow{2}{*}{0.26} \\
\hline $\mathrm{G} 2$ & 0.94 & 8.80 & & & \\
\hline \multicolumn{6}{|l|}{ Tasarım } \\
\hline $\mathrm{T} 1$ & 0.90 & & \multirow{4}{*}{0.90} & \multirow{4}{*}{0.71} & \multirow{4}{*}{0.21} \\
\hline $\mathrm{T} 2$ & 0.86 & 15.73 & & & \\
\hline $\mathrm{T} 3$ & 0.85 & 15.44 & & & \\
\hline $\mathrm{T} 4$ & 0.73 & 11.71 & & & \\
\hline \multicolumn{6}{|c|}{ Güvenlik/Gizlilik } \\
\hline GG1 & 0.88 & 14.89 & \multirow{4}{*}{0.91} & \multirow{4}{*}{0.73} & \multirow{4}{*}{0.28} \\
\hline GG2 & 0.89 & 16.45 & & & \\
\hline GG3 & 0.81 & 16.75 & & & \\
\hline GG4 & 0.82 & & & & \\
\hline \multicolumn{3}{|c|}{ Bilginin Niteliği } & \multirow{4}{*}{0.88} & \multirow{4}{*}{0.72} & \multirow{4}{*}{0.32} \\
\hline B1 & 0.83 & 16.76 & & & \\
\hline B2 & 0.84 & 17.06 & & & \\
\hline B3 & 0.86 & 18.61 & & & \\
\hline \multicolumn{3}{|c|}{ İtkisel Satın Alma Dürtüsü } & \multirow{6}{*}{0.93} & \multirow{5}{*}{0.78} & \multirow{5}{*}{0.53} \\
\hline S1 & 0.92 & & & & \\
\hline S2 & 0.85 & 16.19 & & & \\
\hline S3 & 0.89 & 13.51 & & & \\
\hline S4 & 0.87 & 14.08 & & & \\
\hline Hedonik G & & & & & \\
\hline HG1 & 0.84 & & & & \\
\hline HG2 & 0.79 & 11.76 & 0.87 & 0.70 & 0.41 \\
\hline HG3 & 0.87 & 13.15 & & & \\
\hline $\begin{array}{l}\text { Çevrim içi } \\
\text { Alma }\end{array}$ & & & & & \\
\hline ÇDS1 & 0.86 & & & & \\
\hline ÇDS2 & 0.90 & 16.94 & & & \\
\hline
\end{tabular}




\begin{tabular}{|c|c|c|c|c|c|}
\hline ÇDS3 & 0.89 & 17.91 & \multirow{3}{*}{0.94} & \multirow{3}{*}{0.79} & \multirow{3}{*}{0.54} \\
\hline ÇDS4 & 0.84 & 14.82 & & & \\
\hline ÇDS5 & 0.90 & 16.48 & & & \\
\hline
\end{tabular}

Modelde uyum geçerliliği için maddelerinin standardize edilmiş faktör yüklerinin 0.70'in üzerinde değerlere sahip olması arzu edilmektedir (Kline, 2011). Tablo 3'de standardize faktör yüklerinin, kompozit geçerlilik değerlerinin 0.70 'in üzerinde ve yine ortalama açıklanan varyans değerlerinin de 0.50 'den büyük olduğunu görülmektedir. Ayırt edici geçerlilik kriterinin sağlanabilmesi için MSV<AVE ve AVE'nin karekökünün faktörler arası korelasyondan büyük olması gerekmektedir (Yaşlıoglu, 2017: 83). Çokluk vd. (2016)'nun belirttiği şekilde, $t$ değerlerinin de 0.01 düzeyinde (2.56 değerinden büyük) anlamlı olduğu anlaşılmaktadır. Tabloda KK1, EK1, G1, T1, GG1, B1, S1, IHG1 ve ÇİS1 analiz sırasında referans değeri olarak 1'e eşitlendiğinden t değeri bulunmamaktadır. Model uyum indeksleri değerlerinin de kabul edilebilir ölçülerde olduğu görülmektedir.

Tablo 4'de açıklanan varyans değerlerinin karekökünün boyutlar arası en yüksek korelasyon değerinden büyük olması gerekmektedir (Kline, 2011: 116). Dolayısıyla bu kriterin de sağlandığı görülmektedir.

Tablo 4. Korelasyon Katsayıları ve Açıklanan Varyansların Karekök Değerleri

\begin{tabular}{|lccccccccc|}
\hline \multicolumn{1}{|c}{ Değişkenler } & $\mathbf{1}$ & $\mathbf{2}$ & $\mathbf{3}$ & $\mathbf{4}$ & $\mathbf{5}$ & $\mathbf{6}$ & $\mathbf{7}$ & $\mathbf{8}$ & $\mathbf{9}$ \\
\hline Etkileşim ve Kişiselleştirme & $\mathbf{0 . 8 3 7}$ & & & & & & & & \\
\hline Kullanım Kolaylı̆̆ & 0.330 & $\mathbf{0 . 8 8 9}$ & & & & & & \\
\hline Güven & 0.514 & 0.227 & $\mathbf{0 . 8 5 4}$ & & & & & \\
\hline Bilginin Niteliği & 0.389 & 0.574 & 0.407 & $\mathbf{0 . 8 4 8}$ & & & & \\
\hline Tasarım & 0.397 & 0.356 & 0.278 & 0.463 & $\mathbf{0 . 8 4 2}$ & & & & \\
\hline Güvenlik/Gizlilik & 0.517 & 0.294 & 0.437 & 0.475 & 0.232 & $\mathbf{0 . 8 5 4}$ & & & \\
\hline Çevrim içi İtkisel S.Alma & 0.196 & 0.195 & 0.148 & 0.134 & 0.306 & 0.228 & $\mathbf{0 . 8 8 9}$ & & \\
\hline Hedonik Gezinme & 0.264 & 0.276 & 0.187 & 0.294 & 0.208 & 0.317 & 0.607 & $\mathbf{0 . 8 3 7}$ & \\
\hline Satın Alma Dürtüsü & 0.233 & 0.141 & 0.162 & 0.122 & 0.138 & 0.412 & 0.518 & 0.473 & $\mathbf{0 . 8 8 3}$ \\
\hline
\end{tabular}

Not: AVE karekökleri köşegen (diagonal) ve koyu olarak verilmiştir.

\subsubsection{Yapısal Analiz ve Hipotez Testi Sonuçları}

Araştırmaya ait model doğrulandıktan sonra, hipotezler test edilmiştir. Analiz sonucunda, gizil faktörlerin gözlemlenebilen faktörleri açıklama durumlarına ait $\mathrm{t}$ değerlerinin anlamlı olduğu görülmektedir. Modelin uyum iyiliği değerlerinin de literatürde istenen aralıklarda olduğu görülmektedir. Yapısal modelin uyum iyiliği değerlerine ilişkin bulgular Tablo 5'de gösterilmiştir. 
Tablo 5. Yapısal Model Uyum İyiliği Değerleri

\begin{tabular}{|c|c|}
\hline Uyum İndeksi & $\begin{array}{c}\text { YEM Sonucu } \\
\text { Elde Edilen Değer }\end{array}$ \\
\hline$\chi^{2} / \mathrm{df}$ & 2.80 \\
\hline RMSEA & 0.05 \\
\hline GFI & 0.89 \\
\hline CFI & 0.96 \\
\hline NFI & 0.90 \\
\hline NNFI & 0.95 \\
\hline
\end{tabular}

Tablo 6'da araştırma modelinde öngörülen ilişkilere ait yol analizi sonuçları ve hipotezler gösterilmektedir.

Tablo 6. Yol Analizi Sonuçları ve Hipotezler

\begin{tabular}{|c|c|c|c|c|}
\hline Hipotezler & $\begin{array}{c}\text { Standardize Edilmiş } \\
\text { Yol Katsayısı }\end{array}$ & t değeri & $\mathbf{P}$ & $\mathbf{R}^{2}$ \\
\hline $\begin{array}{l}\text { H1: S.Alma Dürtüsü } \quad<--- \\
\text { Kullanım Kolaylığ1 }\end{array}$ & 0.06 & $\begin{array}{l}0.64 \\
0.52\end{array}$ & & \multirow{7}{*}{0.468} \\
\hline $\begin{array}{l}\mathbf{H}_{2}: \text { S.Alma Dürtüsü <--- Etki. } \\
\text { /Kişiselleştirme }\end{array}$ & 0.15 & $\begin{array}{l}1.49 \\
0.13 \\
\end{array}$ & & \\
\hline H3: S.Alma Dürtüsü <--- Güven & 0.13 & $\begin{array}{l}1.35 \\
0.18\end{array}$ & & \\
\hline $\begin{array}{l}\text { H4: S.Alma } \\
\text { Tasarım }\end{array}$ & 0.32 & $\begin{array}{l}3.78 \\
* * * \\
\end{array}$ & & \\
\hline $\begin{array}{l}\text { H5: S.Alma Dürtüsü <--- } \\
\text { Güvenlik/gizlilik }\end{array}$ & 0.33 & $\begin{array}{l}3.55 \\
* * *\end{array}$ & & \\
\hline 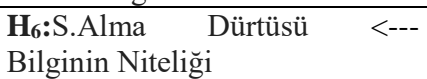 & 0.02 & $\begin{array}{l}0.07 \\
0.98\end{array}$ & & \\
\hline $\begin{array}{l}\text { H}_{7} \quad \text { S.Alma Dürtüsü }<--- \\
\text { Hedonik Gezinme }\end{array}$ & 0.51 & $\begin{array}{l}7.58 \\
* * *\end{array}$ & & \\
\hline $\begin{array}{l}\text { Hs: Çevrim içi İtkisel S. Alma } \\
\text { <--Hedonik Gezinme }\end{array}$ & 0.36 & $\begin{array}{l}4.86 \\
* * *\end{array}$ & & \multirow[t]{2}{*}{0.613} \\
\hline $\begin{array}{l}\text { H9: Çevrim içi İtkisel S. Alma } \\
\text { <--- S.Alma Dürtüsü }\end{array}$ & 0.54 & $\begin{array}{l}7.36 \\
* * *\end{array}$ & & \\
\hline
\end{tabular}

Tablo 6'da yer alan bulgulara göre, t değerleri sırası ile $0.64,1.49,1.35$ ve 0.08 olan ve p>0.05 değerlerine sahip $\mathrm{H}_{1}, \mathrm{H}_{2}, \mathrm{H}_{3}$ ve $\mathrm{H}_{6}$ hipotezleri reddedilmiştir. Elektronik hizmet kalite boyutlarından kullanım kolaylığı, etkileşim/kişiselleştirme, güven ve bilginin niteliği değişkenlerinin bireylerin itkisel satın alma dürtüsü üzerinde anlamlı bir etkisinin olmadığ 1 görülmekte iken t değerleri 3.78 ve 3.55 olan ve $\mathrm{p}<0.05$ değerlerine sahip $\mathrm{H}_{4}$ ve $\mathrm{H}_{5}$ hipotezleri desteklenmiştir. Elektronik hizmet kalite boyutlarından tasarım ve güvenlik/gizlilik değişkenlerinin bireylerin itkisel satın alma dürtüsü üzerinde anlamlı bir etkisinin olduğu görülmektedir.

Bireylerin internette hedonik gezinmesi- itkisel satın alma dürtüsü ve çevrim içi itkisel satın alma ilişkisi ile ilgili olan $\mathrm{H}_{7}$ ve $\mathrm{H}_{8}$ hipotezleri desteklenmiştir. Dolayısıyla bireylerin internette hedonik gezinmelerinin itkisel satın alma dürtüsü ve çevrim içi itkisel satın alma üzerinde anlamlı etkisinin olduğu görülmektedir. Son olarak bireylerin itkisel satın alma dürtüsü faktörünün, çevrim içi itkisel satın alma üzerinde anlamlı bir etkisinin gözlemlendiği anlaşılmaktadır. $\mathrm{Bu}$ nedenle $\mathrm{H}_{9}$ hipotezinin de desteklendiği görülmektedir. Tabloda görüldüğü üzere; elektronik hizmet kalite boyutunu oluşturan değişkenler, itkisel satın alma 
dürtüsünün \%46.8'ini $\left(\mathrm{R}^{2}\right)$; itkisel satın alma dürtüsü ve internette hedonik gezinme faktörleri de çevrim içi itkisel satın almanın \%61.3’ünü $\left(\mathrm{R}^{2}\right)$ açıklamaktadır.

\section{SONUÇ}

Elektronik ticaretin gelişmesi ile birlikte tüketicilerin farklı alışveriş sitelerinden çevrim içi alışveriş yapma olanakları artmıştır. Dolayısıyla rekabetin yoğun olduğu çevrim içi alışveriş sitelerinin, müşterilerinin planlı ve rasyonel satın alma davranışı dışında da itkisel satın alma dürtüsünü harekete geçirerek anlık, dürtüsel olarak sergiledikleri itkisel satın alma davranışını etkileyebilmeleri daha çok önem kazanmaktadır. Araştırmada elektronik hizmet kalite boyutlarından güvenlik/gizlilik ve tasarımın bireylerin itkisel satın alma dürtüsünü harekete geçirerek itkisel satın alma davranışı sergilemelerine neden olduğu sonucuna ulaşılmıştır. Bunun yanı sıra, bireylerin duygusal durumlarına bağlı olarak gelişen ve eğlence boyutuyla öne çıkan internette hedonik gezinmenin de bireylerde itkisel satın alma dürtüsünü ve itkisel satın alma davranışını etkilediği ortaya çıkmaktadır.

Araştırmada alışveriş yapılan internet sitesinin kolay kullanımı ile itkisel satın alma dürtüsü ilişkisini inceleyen $\mathrm{H}_{1}$ hipotezi desteklenmemiştir. Yani, elektronik hizmet kalite boyutlarından internet sitesinin kolay kullanımı ile itkisel satın alma dürtüsü arasında anlamlı bir ilişki yoktur. İnternet sitesinin kolay kullanımı, bireylerin kullandıkları internet sitesinin fonksiyonel özelliklerini hılı ve basit bir biçimde algılayıp kullanabilmelerini ifade etmektedir (Brown, 2002: 3). Dolayısıyla, ülkemizdeki bireylerin, alışveriş yaptıkları web sitelerinin kolay kullanım özelliklerini, itkisel satın alma dürtülerini harekete geçirecek şekilde ayırt edici ve teşvik edici bulmadıkları söylenebilir ya da daha önceden çevrim içi alışveriş yapan bireyler geçmiş tecrübeleri ile internet sitelerinden alışveriş ile ilgili bilgi toplama, ürün karşılaştırma vb. becerilere sahip olabilmektedir. İlgili literatüre bakıldığında, araştırmanın aksine çoğu araştırmacı (Bressolles, 2007; Verhagen ve Dolen, 2011; Türkyılmaz, Erdem ve Uslu, 2015) kullanım kolaylığı - itkisel satın alma dürtüsü arasında anlamlı bir ilişkinin varlığından söz ederken; Liu vd. (2013) araştırmamıza benzer şekilde iki faktör arasında anlamlı bir ilişkinin olmadığı sonucuna ulaşmıştır.

Araştırma sonucunda, elektronik hizmet kalite boyutlarından etkileşim/kişiselleştirme ile itkisel satın alma dürtüsü arasında anlamlı bir ilişkinin olmadığı ortaya çıktığı için $\mathrm{H}_{2}$ hipotezi desteklenmemiştir. Mvangi ve arkadaşları, araştırmanın aksine 2018 yılında yaptıkları çalışmalarında, katılımcıların tatil yapmayı planladıkları yerleri seçecekleri internet sitesinin etkileşim/kişiselleştirmesinin satın alma kararı vermelerinde en önemli unsurlarından birisi olduğunu belirtmişlerdir. Bressoles (2007), elektronik hizmet kalite boyutlarının itkisel satın almaya etkisi ve itkisel satın alma sonrası tatmin faktörlerine etkisini bulmaya çalıştığı araştırmasında, aynı şekilde çevrim içi itkisel satın alma ile etkileşim/kişiselleştirme arasında anlamlı bir ilişkinin olduğunu ifade ederken; Pappas ve arkadaşları (2014) yaptıkları araştırmada etkileşim/kişiselleştirmenin bireylerde mutluluk hissiyatı yarattığını ve dürtüsel satın alma isteklerini harekete geçirdiğini belirtmişlerdir.

Araştırma modelinde yer alan elektronik hizmet kalite faktörlerinden birisi olan güven faktörünün, "itkisel satın alma dürtüsünü pozitif yönde etkilemektedir" şeklindeki $\mathrm{H}_{5}$ hipotezi reddedilmiştir. Ülkemizde itkisel satın alma dürtüsü ile hareket eden bireyler, çevrim içi alışveriş sırasında sitenin güvenilir olup olmamasını değerlendirmemektedirler. Bressolles (2007), araştırmamıza paralel şekilde güven faktörünün itkisel satın almaya anlamlı etkisinin olmadığını ifade etmiştir. 
İtkisel satın alma dürtüsü - internet sitesi tasarımı ilişkisini irdeleyen $\mathrm{H}_{4}$ hipotezi desteklenmiştir. İnternet sitesinin grafik detayları, renkleri, animasyonların kullanılması gibi görsel öğeleri içeren internet sitesinin tasarımı bireylerin satın alma dürtüsünü pozitif olarak etkilemektedir. Dolayısıyla alışveriş sitelerinin benzerlerinden ayrılması ve görsel unsurlarla farklılaşarak bireylerin satın alma dürtüsünü harekete geçirmeleri gerekmektedir. Literatürdeki çalışmalara bakıldığında, araştırmaya benzer şekilde Liu vd. (2013) internet sitelerin görsel unsurlarının itkisel satın almayı pozitif şekilde etkilediğini ifade ederlerken; Moez (2013), Türkyılmaz vd. (2015) ve Bressoles vd. (2007) internet sitesi tasarımının dürtüsel satın almayı etkileyen en önemli kalite boyutlarından birisi olduğunu belirtmişlerdir.

Araştırma sonucunda, elektronik hizmet kalite boyutlarından güvenlik/gizlilik ile itkisel satın alma dürtüsü arasında anlamlı bir ilişkinin varlığı ortaya çıktığı için $\mathrm{H}_{5}$ hipotezi desteklenmiştir. Bireyler, alışveriş yapmak istedikleri internet sitelerinde kişisel bilgilerinin korunduğundan, başka kurum ya da kişilerle bu bilgilerin paylaşılmadığından ve banka hesaplarının, kredi kartlarının doğal olarak ileri ve gelişmiş güvenlik sistemleri ile koruma altına alındığından emin olmak istemektedirler. Dolayısıyla, işletmeler bireylerin itkisel satın alma dürtüsü ile hareket etmelerini istiyor ve bu dürtünün de satın alma davranışına dönüşmesini umuyorlarsa, internet sitelerinin güvenlik/gizlilik niteliğini geliştirmelidirler. Yazılım güvenliği ile ilgili garanti kapsamının genişletilmesi, siber saldırılara karşı güvenlik firmaları ile iş birliği antlaşmalarının imzalanması gibi adımların atılması bu siteleri ilgi çekici ve tercih edilen yapacak; aynı zamanda da bireylerin satın alma dürtülerini harekete geçirecektir. İlgili literatür incelendiğinde, Eroğlu vd. (2001), Nazir vd. (2012) ve Ang vd. (2015), araştırmamıza benzer şekilde güvenlik/gizlilik faktörünün bireylerde itkisel satın alma dürtüsünü tetiklediklerini ve aynı zamanda da çevrim içi itkisel satın alma davranışı sergilenmesi noktasında da pozitif etkisinin olduğunu ifade etmişlerdir.

Elektronik hizmet kalitesinin son boyutu olan bilginin niteliği- itkisel satın alma dürtüsü ilişkisini açıklamaya çalışan $\mathrm{H}_{6}$ hipotezi desteklenmemiştir. Bilginin niteliği boyutu, çevrim içi satın alma yapacak internet kullanıcılarının ürün, hizmetler, satış söleşmeleri vb. konularda algılarını ifade etmektedir (Bressolles, 2007: 39). Dolayısıyla, itkisel satın alma dürtüsü ile hareket edecek bir bireyin satış ve ürün teslimatı ile ilgili sözleşme detaylarını incelemesi vb. beklenemeyeceği için şaşırtıcı bir sonuç ortaya çıkmamıştır. Araştırmaya paralel olarak Tinne (2010), Muruganantham ve Bhakat (2013) ve Lim ve Yazdanifard (2015) araştırmalarında çevrim içi satış yapan sitelerin bilgi niteliği ile itkisel satın alma dürtüsü arasında anlamlı bir ilişkinin bulunmadığını belirtmişlerdir.

Araştırmada, internette hedonik gezinme- itkisel satın alma dürtüsü ilişsisini inceleyen $\mathrm{H}_{7}$ ve internette hedonik gezinme- itkisel satın alma davranışı ilişkisini inceleyen $\mathrm{H}_{8}$ hipotezi desteklenmiştir. Ülkemizde yaşayan bireylerin, internet sitelerinde harcadıkları zaman arttıkça ve gezdikleri internet sitelerinden duydukları haz ve keyif çoğaldıkça, satın alma dürtüleri de artacaktır. Çevrim içi satış yapan internet sitelerinin eğlenceli olması, bireylerin plansız ve spontane şekilde satın alma dürtüsü ile hareket etmelerine neden olabilmektedir. Hedonik faydayı gözeten internet kullanıcıları da internet sitelerinde farklı sebeplerle (Sorunlarından anlık olarak uzaklaşmak, sakinleşmek, oyalanmak vb.) de olsa geçirdikleri zaman dilimi içerisinde dürtüleri ile itkisel satın alma davranışı gösterebilmektedirler. Dolayısıyla pazarlama uzmanlarının müşterilerin internette daha fazla keyifli şekilde zaman harcamalarını sağlayacak detayları keşfetmeleri ve yazılım uzmanları ya da programcılara uygulatmaları gerekmektedir. Gültekin ve Özer (2012), Park vd. (2012), Verhagen ve Dolen 
(2011), Rezaei vd. (2016) yaptıkları araştırmalarda internette hedonik gezinmenin itkisel satın alma dürtüsü ve itkisel satın alma davranışını anlamlı ve pozitif şekilde etkilediğini belirtmişlerdir.

Araştırmanın son hipotezi itkisel satın alma dürtüsü- çevrim içi itkisel satın alma davranışı ilişkisini inceleyen $\mathrm{H}_{9}$ hipotezi literatürde yapılan geçmiş araştırmalara (Hanzaeeve Taherikia, 2010; Verhagen ve Dolen, 2011; Foroughi vd., 2013) benzer şekilde kabul edilmiştir. İtkisel satın alma dürtüsü, itkisel satın alma davranışını anlamlı ve pozitif olarak etkilemektedir. Bireyler, itkisel satın alma dürtüsü ile hareket ettiklerinde, gezindikleri internet sitelerinde gördükleri ürünü o anlık hissettikleri ile genellikle de fonksiyonel faydasını düşünmeden satın alma düşüncesine sahip olmaktadırlar (Madhavaram ve Laverie, 2004). Dolayısıyla, çevrim içi satış yapan işletmelerin amaçları, bireylerin itkisel satın alma dürtüsünü hareket ettirmek olmalıdır.

Araştırmanın, elektronik hizmet kalite boyutlarının her birinin ayrı bir hipotezi oluşturması ve modelde yer alan itkisel satın alma dürtüsü faktörüyle olan ilişkilerinin bulunması, yine itkisel satın alma dürtüsünün itkisel satın alma davranışını aracı olarak etkilemesinin ortaya konulması açısından literatüre ve uygulamacılara katkı sağlayacağı düşünülmektedir.

Araştırmanın kısıtları ele alındığında, verilerin kolayda örnekleme yöntemiyle elde edilmesi sonuçların genelleme yapılarak değerlendirilmesini zorlaştırmaktadır. Kısıtlı olanaklar yüzünden sadece belirli bölgede yer alan ve yine belirli sayıda tüketiciye ulaşılması da araştırmanın diğer kısıtını oluşturmaktadır. İleride yapılacak benzer çalışmalarda, bireylerin belirli ürün grupları ya da markalar için itkisel satın alma davranışına etki edebilecek ve araştırma modeline eklenebilecek farklı faktörlerle (internette faydacı gezinme, bireylerin duygu durumunu gösteren olumlu etki ve olumsuz etki vb.) çalışmalar yapıllması literatüre katkı sağlaması ve farklılıkların ortaya konulması için önemlidir.

\section{KAYNAKÇA}

AKRAM, U., HUI, P., KHAN, M. K., TANVEER, Y., MEHMOOD, K., \& AHMAD, W. (2018). How website quality affects online impulse buying. Asia Pacific Journal of Marketing and Logistics.

ANG, S. S., LIEW, W. Q., WAI, K. C., \& YEOH, W. T. (2015). The influencing factors on generation Y online impulsive buying behaviour (Doctoral dissertation, UTAR).

BARNES, S. J., \& VIDGEN, R. T. (2002). An integrative approach to the assessment of ecommerce quality. J. Electron. Commerce Res., 3(3), 114-127.

BEATTY, S. E., \& FERRELL, M. E. (1998). Impulse buying: Modeling its precursors. Journal of Retailing, 74(2), 169-191.

BITNER, M.J., BROWN, S.B., \& MEUTER, M.L. (2000), “Technology infusion in Service Encounters", Journal of the Academy of Marketing Science, 28 (1), 138-149.

BRESSOLLES, G., DURRIEU, F., \& GIRAUD, M. (2007). The impact of electronic service quality's dimensions on customer satisfaction and buying impulse. Journal of Customer Behaviour, 6(1), 37-56. 
BROWN, I. T. (2002). Individual and technological factors affecting perceived ease of use of web-based learning technologies in a developing country. The Electronic Journal of Information Systems in Developing Countries, 9(1), 1-15.

CHAKRABORTY, S. (2017). An Empirical Investigation On The Association Between Consumer Online Impulsive Buying Behavior And Website Quality-A Study With Special Reference To Flipkart Online Store. Imperial Journal of Interdisciplinary Research (IJIR), 3, 2454-1362.

CHAN, T. K., CHEUNG, C. M., \& LEE, Z. W. (2017). The state of online impulse-buying research: A literature analysis. Information \& Management, 54(2), 204-217.

CHEN, Y., \& ZHANG, L. (2015). Influential factors for online impulse buying in China: a model and its empirical analysis. In Proceedings of the International Conference on eLearning, e-Business, Enterprise Information Systems, and e-Government (EEE) (p. 45).

CHEN, J. V., SU, B. C., \& WIDJAJA, A. E. (2016). Facebook C2C social commerce: A study of online impulse buying. Decision Support Systems, 83, 57-69.

ÇOKLUK, Ö., ŞEKERCİOĞLU, G., \& BÜYÜKÖZTÜRK, Ş. (2016). Sosyal Bilimler İçin Çok Değişkenli İstatistik SPSS ve LISREL Uygulamaları, 4. Baskı, Ankara, Pegem Akademi Yayınları.

DAWSON, S., \& KIM, M. (2009). External and internal trigger cues of impulse buying online. Direct Marketing: An International Journal, 3(1), 20-34.

DEWI, M. A. A., NURROHMAH, I., SAHADI, N., SENSUSE, D. I., \& NOPRISON, H. (2017, October). Analysing the critical factors influencing consumers'e-impulse buying behavior. In 2017 International Conference on Advanced Computer Science and Information Systems (ICACSIS) (pp. 81-92). IEEE.

DHOLAKIA, U.M. (2000)," Temptation and resistance: an integrated model of consumption impulse". Psycholgy and Marketing. 17 (11), 955-982.

DITTMAR, H., LONG, K., \& MEEK, R. (2004). Buying on the Internet: gender differences in online and conventional buying motivations. Sex Roles, 50 (5-6), 423-444.

EROĞLU, S. A., MACHLEIT, K. A., \& DAVIS, L. M. (2001). Atmospheric qualities of online retailing: A conceptual model and implications. Journal of Business Research, 54(2), 177-184.

FOROUGHI, A., BUANG, N. A., SENIK, Z. C., \& HAJMISADEGHI, R. S. (2013). Impulse buying behavior and moderating role of gender among Iranian shoppers. Journal of Basic and Applied Scientific Research, 3(4), 760-769.

GÜLTEKİN, B. (2012). The influence of hedonic motives and browsing on impulse buying. Journal of Economics and Behavioral Studies, 4(3), 180-189.

HÄUBL, G., \& TRIFTS, V. (2000). Consumer decision making in online shopping environments: The effects of interactive decision aids. Marketing science, 19(1), 4-21. 
HABIB, M. D., \& QAYYUMB, A. (2017). A Structural Equation Model of Impulse Buying Behavior in Online Shopping. UW Journal of Management Sciences, 1, 1-14.

HAIR, J.F., BLACK, W.C., BABIN, B.J., \& ANDERSON, R.E. (2010). Multivariate Data Analysis, Seventh Edition, NewYork, Prentice Hall.

HANZAEE, K. H., \& TAHERIKIA, F. (2010). Impulse buying: an Iranian model. ChinaUSA Business Review, 9(12), 31.

HANZAEE, K. H., NOROUZI, A., \& GHALANDARI, K. (2011). The Effect of İnvolvement On Utilitarian and Hedonic Products Knowledge. World Applied Science Journal, 13(7), 1635-1642.

HASIMA, M. A., ISHAKB, M. F., \& HASSIMC, A. (2019). The Relationship between Online Shopping Environments, Sales Promotions, Website Quality, and Impulsive Buying Behaviour: A Structural Equation Modelling Approach. International Journal of Innovation, Creativity and Change, 6(9), 216-230.

HO, S. Y., \& TAM, K. Y. (2005). An empirical examination of the effects of web personalization at different stages of decision making. International Journal of HumanComputer Interaction, 19(1), 95-112.

HUANG, M. H. (2005). Web performance scale. Information \& Management, 42(6), 841852.

JONES, M.A., REYNOLDS, K.E., WEUN, S., \& BEATTY, S.E., (2003)," The productspecific nature of impulse buying tendency". Journal of Business Research. 56 (7), 505-511.

KACEN, J. J., \& LEE, J. A. (2002). The influence of culture on consumer impulsive buying behavior. Journal of consumer psychology, 12(2), 163-176.

KAZEMPOUR, Y., \& LOTFIZADEH, F. 2017. The Impact of Situational Factors (Store, Personal) on Urge to Buy Impulsively and Impulse Buying Behavior. European Journal of Buisness and Innovation Research, 5(4), 12-27.

KLINE, R. B. (2011). Principles and practice of structural equation modeling, Third Edition, London, The Guilford Press.

LING, P. L., \& YAZDANIFARD, R. (2015). What internal and external factors influence impulsive buying behavior in online shopping?. Global Journal of Management and Business Research, 15(5), 24-32.

LIU, Y., LI, H., \& HU, F. (2013), "Website Attributes in Urging Online Impulse Purchase: An Empirical Investigation on Consumer Perceptions", Decision Support Systems, 55(3), $829-837$.

MADHAVARAM, S. R., \& LAVERIE, D. A. (2004). Exploring impulse purchasing on the internet. Advances in consumer research, 31(1), 59-66.

MARTINEZ, R., JIMENEZ, Z., \& IZQUIERDO, Y. 2010. Customer satisfaction's key factors in Spanish grocery stores: evidence from hypermarkets and supermarkets. Journal of Retailing and Consumer Services 17(4), 278-285. 
MOEZ, L. (2013). Antecedents and Effect of Commitment on the Impulse Buying By Internet. J.of Internet Banking and Commerce, 18(1), 1-22.

MOHAN, G., SIVAKUMARAN, B., \& SHARMA, P. (2013). Impact of store environment on impulse buying behavior. European Journal of marketing, 47(10), 1-33.

MURUGANANTHAM, G., \& BHAKAT, R. S. (2013). A review of impulsive buying behavior. International Journal of Marketing Studies, 5(3), 149-160.

MWANGI, E. K., KIMANI, S., \& MINDILA, A. Techniques for Prioritizing the Elements of Web-GIS Usability. International Journal of Computer Applications, 179(53), 42-46.

NAKIP, M. (2003). Techniques for Marketing Research and SPSS Supported Applications. Ankara: Seçkin Issues, 183.

NOVAK, T. P., HOFFMAN, D. L., \& DUHACHEK, A. (2003). The influence of goaldirected and experiential activities on online flow experiences. Journal of consumer psychology, 13(1-2), 3-16.

OVERBY, J. W., \& LEE, E. J. (2006). The effects of utilitarian and hedonic online shopping value on consumer preference and intentions. Journal of Business research, 59(10-11), 1160-1166.

PAPPAS, I. O., KOUROUTHANASSIS, P. E., GIANNAKOS, M. N., \& CHRISSIKOPOULOS, V. (2014). Shiny happy people buying: the role of emotions on personalized e-shopping. Electronic Markets, 24(3), 193-206.

PARBOTEEAH, D. V. (2005). A model of online impulse buying: An empirical study.

PARK, E. J., KIM, E. Y., FUNCHES, V. M., \& FOXX, W. (2012). Apparel product attributes, web browsing, and e-impulse buying on shopping websites. Journal of Business Research, 65(11), 1583-1589.

PARSAD, C., PRASHAR, S., \& SAHAY, V. (2017). Impact of Impulsive Personality Traits and Store Environment on Impulse Buying Behavior. Journal of Business \& Management, 23(1-2), 1-24 .

PUNCH, K. F. (2005). Sosyal Araştırmalara Giriş: Nicel ve Nitel Yaklaşımlar, Dursun, BAYRAK, H. Bader, ARSLAN \& Zeynep, AKYÜZ, (Çev.), 1. Baskı, Ankara, Siyasal Yayınevi.

REZAEI, S., ALI, F., AMIN, M., \& JAYASHREE, S. (2016). Online impulse buying of tourism products. Journal of Hospitality and Tourism Technology, 7(1), 60-83.

ROOK, D. W. (1987). The buying impulse. Journal of Consumer Research, 14(2), 189-199.

ROOK, D. W., \& FISHER, R. J. (1995). Normative influences on impulsive buying behavior. Journal of consumer research, 22(3), 305-313.

ROWLEY, J. (2002). 'Window'shopping and browsing opportunities in cyberspace. Journal of Consumer Behaviour: An International Research Review, 1(4), 369-378. 
SHARMA, P., SIVAKUMARAN, B., \& MARSHALL, R. (2010), "Impulse buying and variety seeking: A trait-correlates perspective", Journal of Business Research, 63(3), 276-283.

SHIRMOHAMMADI, M., GHANE, N., \& EBRAHIMI, M. R. (2015). Investigating and prioritizing the effective factors on internet impulse buying behavior of customers (case study: discount group sites). Business and Management, 7(3), 275-290.

SOHN, H. K., \& LEE, T. J. (2017). Tourists' impulse buying behavior at duty-free shops: the moderating effects of time pressure and shopping involvement. Journal of Travel \& Tourism Marketing, 34(3), 341-356.

STYVÉN, M. E., FOSTER, T., \& WALLSTRÖM, Å. (2017). Impulse buying tendencies among online shoppers in Sweden. Journal of Research in Interactive Marketing, 11(4), 416-431.

TAYLOR, D. C., PARBOTEEAH, D. V., \& SNIPES, M. (2010). Winery websites: Effectiveness explored. Journal of Business Administration Online, 9(2), 1-11.

THEODOSIOU, M., KATSIKEA, E., SAMIEE, S., \& MAKRI, K. (2019). A comparison of formative versus reflective approaches for the measurement of electronic service quality. Journal of Interactive Marketing, 47, 53-67.

TRANDAFILOVIĆ, I., PAŠIĆ, V., \& PERUNOVIĆ, S. (2013). The research of cognitive and affective behaviour during shopping. Economics and Organization, 10(2), 147164.

TINNE, W. S. (2010). Impulsive purchasing: A literature overview. ASA University Review, $4(2), 65-73$.

TÜRKYILMAZ, C. A., ERDEM, Ş., \& USLU, A. (2015), "The Effects of Personality Traits and Website Quality on Online Impulse Buying", Procedia - Socialand Behavioral Sciences, $175,98-105$.

VERHAGEN, T., \& VAN DOLEN, W. (2011). The influence of online store beliefs on consumer online impulse buying: A model and empirical application. Information \& Management, 48(8), 320-327.

YAŞLIOĞLU, M. M. (2017). Sosyal bilimlerde faktör analizi ve geçerlilik: Keşfedici ve doğrulayıcı faktör analizlerinin kullanılması. İstanbul Üniversitesi İşletme Fakültesi Dergisi, 46, 74-85.

VERPLANKEN, B., \& HERABADI, A. (2001). Individual differences in impulse buying tendency: Feeling and no thinking. European Journal of personality, 15(S1), 71-83.

WELLS, J. D., PARBOTEEAH, V., \& VALACICH, J. S. (2011). Online impulse buying: understanding the interplay between consumer impulsiveness and website quality. Journal of the Association for Information Systems, 12(1), 3.

YANG, K., \& YOUNG, A. P. (2009). The effects of customized site features on internet apparel shopping. Journal of Fashion Marketing and Management: An International Journal, 13(1), 128-139. 
YU, C., \& BASTIN, M. (2010). Hedonic shopping value and impulse buying behavior in transitional economies: A symbiosis in the Mainland China marketplace. Journal of Brand Management, 18(2), 105-114.

ZEITHAML, V. A., PARASURAMAN, A., \& MALHOTRA, A. (2000). E-service quality: Definition, dimensions and conceptual model. Marketing Science Institute, Cambridge, MA, working paper.

ZEITHAML, V. A., PARASURAMAN, A., \& MALHOTRA, A. (2002). Service quality delivery through web sites: a critical review of extant knowledge. Journal of the academy of marketing science, 30(4), 362-375. 